Article

\title{
Contributions to Sustainability in SMEs: Human Resources, Sustainable Product Innovation Performance and the Mediating Role of Employee Creativity
}

\author{
Lucía Muñoz-Pascual ${ }^{1, *}$, Jesús Galende ${ }^{1}\left(\mathbb{D}\right.$ and Carla Curado ${ }^{2} \mathbb{D}$ \\ 1 Department of Business Administration and Management, Campus "Miguel de Unamuno", \\ Multidisciplinary Institute for Enterprise (IME), University of Salamanca, Building FES, \\ 37007 Salamanca, Spain; jgalende@usal.es \\ 2 Advance/CSG ISEG, University of Lisbon, Rua do Quelhas, 6, 1200-781 Lisbon, Portugal; \\ ccurado@iseg.ulisboa.pt \\ * Correspondence: luciamp@usal.es; Tel.: +34-923-294-500 (ext. 6825)
}

check for updates

Citation: Muñoz-Pascual, L.; Galende, J.; Curado, C. Contributions to Sustainability in SMEs: Human Resources, Sustainable Product Innovation Performance and the Mediating Role of Employee Creativity. Sustainability 2021, 13, 2008. https://doi.org/10.3390/ su13042008

Academic Editor:

Christian Vandenberghe

Received: 20 January 2021

Accepted: 4 February 2021

Published: 13 February 2021

Publisher's Note: MDPI stays neutral with regard to jurisdictional claims in published maps and institutional affiliations.

Copyright: (c) 2021 by the authors. Licensee MDPI, Basel, Switzerland. This article is an open access article distributed under the terms and conditions of the Creative Commons Attribution (CC BY) license (https:// creativecommons.org/licenses/by/ $4.0 /)$.

\begin{abstract}
The analysis of human resources and sustainable innovation through organizational variables is useful, albeit limited, for predicting complex interactions for sustainability development in small and medium-sized enterprises (SMEs). This paper seeks to overcome this limitation, proposing three models with variables at two levels, namely, for the development of creativity (individual level) and sustainable product innovation performance (organizational level) and sustainability development. Theoretical models are tested using the Structural Equations Model. It is posited that knowledge, motivation, and relationships (individual level) may be predictors of creativity. In addition, creativity is analyzed as a mediator between human resources and sustainable product innovation performance. In this way, it is easier for SMEs to detect on which aspects of HR they should place greater emphasis for sustainable product innovation performance (PIP), with the purpose of reducing the ones associated with the Covid-19 crisis and obtaining a sustainable world. Information was obtained through an online questionnaire involving a sample of 245 certified innovative Spanish SMEs. The results support major findings: (a) knowledge, (b) motivation, and (c) relationships have a positive impact on creativity; (d) the three models hold that creativity fully mediates human resources and sustainable product innovation performance. The paper contributes to the literature on the human resources and sustainable product innovation performance by adopting a multidisciplinary approach, as well as by analyzing variables on two levels, measuring the most internal aspects of employees (wishes, emotions, ideas, or feelings), and explaining the mediating role of employee creativity.
\end{abstract}

Keywords: small- and medium-sized enterprises; sustainable product innovation performance; creativity; human resources; knowledge; motivation; relationships

\section{Introduction}

The concepts of human resources (HR) and sustainable product innovation performance (PIP) are two strategic elements that every company should promote in the pursuit of management excellence, and therefore market success. HR and sustainable innovation should be the guiding principles of management action for improving business results. These two elements have become highly relevant in "management" literature.

Numerous authors have reported that proper HR management improves innovation results [1-3]. Nevertheless, few authors have measured and investigated this matter within HR dimensions (intellectual, emotional, and social), i.e., the detailed composition or proposed contingent relationships, including creativity between HR and sustainable PIP, or reported models with variables at different levels (e.g., individual and organizational) $[4,5]$. 
One of the theoretical perspectives supporting these relationships is the ResourceBased View (RBV), which argues that firms will try to manage their valuable resources to generate new sources of competitive advantage [6-9].

This paper considers that the study of HR should not simply focus on a certain orientation (exploitation or exploration). Each SME is contextualized within a sector with different conditions and characteristics. If only one orientation is analyzed, some companies may then appear to be efficient, but others may not. An in-depth independent study of dimensions and resources is required to generate greater innovation results. This paper begins by focusing on sustainable PIP. It is the most visible form of innovation for clients, and will lead companies to obtain greater benefits more directly [10]. The ambidexterity perspective has distinguished two major orientations of HR [11-14]. On the one hand, sustainable PIP is associated with the accumulation and exploitation of existing resources (stock generator), and on the other hand, with organizations that learn, explore, and innovate (flow generator) [15]. Those organizations that choose HR oriented towards a single form will therefore be short-sighted. Both these approaches take opposite, yet at the same time complementary, directions [15].

The problem is that most organizations implement HR systems in which it is difficult to distinguish their orientation. This paper seeks to differentiate, within HR dimensions, the employee resources managed by organizations from one perspective or another, or both.

Exploration-oriented HR aim to develop the most tacit part of knowledge, the most intrinsic part of motivation, and the most informal part of relationships within organizations. This orientation deals with internal and informal aspects of employees, which can be decisive for developing creativity and innovation. Furthermore, exploitation-oriented HR set out to develop explicit knowledge, extrinsic motivation, and formal employee relationships [11-15].

The research questions are: How does knowledge contribute to the development of sustainable innovations in SMEs?; How does motivation contribute to the development of sustainable innovations in SMEs?; How do relationships contribute to the development of sustainable innovations in SMEs?; Can creativity act as a contingency mechanism between knowledge, motivation, relationships, and the development of sustainable innovations in SMEs?

Therefore, some of this paper's main contributions to the literature on HR and sustainable PIP are as follows: first, it considers individual resources belonging to each HR dimension: intellectual capital (knowledge), emotional capital (motivation), and social capital (relationships) [16,17]. Second, three HR orientations (tacit/explicit knowledge, intrinsic/extrinsic motivation, and informal/formal relationships) are taken into account to measure variables, despite the difficulty in measuring individuals' most internal, informal, or intrinsic aspects. Third, the study includes a key measure of employee creativity, namely, the Torrance Tests of Creative Thinking (TTCT) [18], which have been widely used and validated in studies in other fields such as education and psychology, but not in management research [19]. In this sense, this study's multidisciplinary approach allows advancing within the field of creativity in a business context. Fourth, the paper reveals that there may be another kind of indirect contingent relationship that mediates between HR and sustainable PIP, whereby the direct relationship between them is affected by another variable that can alter their in- SMEs relationship, namely, creativity. Creativity is proposed as an antecedent of sustainable PIP, and as a mediator between it and HR.

In sum, the paper proposes three examples of Structural Equation Modeling (SEM), with variables at two levels (individual and organizational), where the research hypotheses are tested. Knowledge, motivation, and relationships are individually analyzed (employee level), as is creativity, and sustainable PIP is analyzed at the organizational level. In this vein, authors such as Long [20] argue that further multidisciplinary research (management and psychology) is needed with new complex quantitative methodologies, mixed methods, and a different analysis level and context. 
The paper is structured as follows. After this introduction, the theoretical framework supporting the investigation is explained, and the main hypotheses are presented. The methods used in this paper are explained below, including data and sample characteristics, measures of variables, and the main results obtained in SEM. Finally, the main findings, conclusions, and practical implications are presented.

\section{Theory Development}

The theoretical approach that supports the paper is the Resource-Based View (RBV) [6-8,21]. It allows to explain how the influence of valuable resources such as HR have a positive impact on organizations. Accordingly, the company will be concerned with maintaining and caring for HR in a way that encompasses not only their knowledge, skills and experiences, but also their attitudes and relationships with other members of the organization. However, even though this is the paper's main theoretical approach, it will also make implicit reference to other approaches, such as the Knowledge-Based View (KBV) [21-23]. This theoretical approach will explain how knowledge has a direct effect on creativity and sustainable PIP. In addition, support is also provided by Behavioral Theory [24], which explains how motivation has a direct effect on creativity and sustainable PIP. Other theories, such as Human Relations Theory or Cooperative Systems Theory, also provide theoretical support for the effects between relationships, employee motivation, and sustainable PIP. A recent approach called the Ambidextrous Organizations Approach supports the management of HR according to its orientation (exploitation and/or exploration) [11,12,14].

To conclude with the conceptual model's theoretical background, this paper considers Evolutionary Theory $[25,26]$, which explains the innovation process from a dynamic perspective based on different learning patterns that firms may embrace by exploiting internal and external factors. Evolutionary Theory uses generic processes (variation, selection, retention, and competition) to explain how organizations emerge and evolve. Dissecting strategy-making in terms of these key processes serves two purposes: First, it facilitates integrating strategy-making as adaptive organizational capability into evolutionary theory. Second, it illuminates facets of strategy-making that other theoretical perspectives do not contemplate. Each SME is an ecology within which strategic initiatives emerge in patterned ways. Top management drives most initiatives but leaders throughout the organization also drive initiatives. These initiatives compete for limited organizational resources to increase their relative importance.

These theories are the theoretical pillars underpinning the explanation of how HR can improve creativity and sustainable PIP.

Therefore, we propose the following research questions:

- How does knowledge contribute to the development of sustainable innovations?

- How does motivation contribute to the development of sustainable innovations?

- How do relationships contribute to the development of sustainable innovations?

- Can creativity act as a contingency mechanism between knowledge, motivation, relationships and the development of sustainable innovations?

\subsection{Human Resources}

HR should be oriented towards improving firm performance by implementing a culture of values in employees. HR include three dimensions (intellectual, emotional, and social), which when they interact with each other generate synergies, and therefore develop higher organizational capabilities [16]. The continuous improvement of employees may then prompt a major development of ideas, and therefore new sustainable product innovation [27].

Gratton and Ghoshal [16] distinguish three dimensions of HR: intellectual, emotional, and social. Within each dimension, a type of resource will be analyzed at the individual level [1-3]. Knowledge and its impact on sustainable PIP will be analyzed within the intellectual dimension, while within the emotional one, this analysis will focus on motivation and its impact. Finally, and within the social dimension, the analysis will address relation- 
ships and their corresponding impact. HR are therefore divided into three dimensions. The resources are defined below.

Knowledge is based on training people's intellectual resources to enable them to perform well, appropriately, or suitably. Knowledge can be divided into tacit and explicit. Explicit knowledge can be obtained from courses, databases, degrees, and so on. Tacit knowledge cannot be accumulated, but it can be applied through experience, personal life, etc., and it plays a key role in generating new ideas.

Motivation comprises impulses, desires, demands, and the forces that form an individual's mindset. A variety of reasons encourage people to activate and focus their behavior. This may be extrinsic or intrinsic motivation [28]. Extrinsic motivation occurs when individuals satisfy their needs indirectly, mainly through monetary compensation or other external motivations [29]. Intrinsic motivation provides direct satisfaction in two ways-social and self-realization, and it comes from within. Intrinsic motivation can therefore become a key pillar for generating new ideas in organizations [30,31].

Relationships are contacts established between members of an organization among themselves and with other external agents. They may be formal or informal. Formal relationships involve members of an organization or other external agents arising from work and contractual dealings. These relationships usually create weak, short-term ties. Informal relationships are forged between members of an organization or with other external agents, arising from relaxed environments. These relationships go beyond mere labor relations, and serve to gain trust, commitment, and attachment to organization. These relationships forge strong, long-term bonds. When managers know how to manage these informal relationships, they will be able to access new information or knowledge, and therefore new ideas $[17,32]$.

For decades, the study of HR has been based on the most rational part, such as explicit knowledge, extrinsic motivation, and formal relationships. These resources, as sources of stock, are important, but from an exploratory perspective they are not the only ones. To complete the study of $\mathrm{HR}$, it is important to analyze implicit knowledge, intrinsic motivation, and informal relationships. Hence, when measuring variables this paper takes both perspectives into account, despite the difficulty of measuring the more informal part of HR. From this perspective, this second way of analyzing HR may make employee creativity and sustainable PIP more sustainable. These resources are unique, valuable, and inimitable $[7,8,21]$. In addition, rationalization, as the only way to guide $H R$, may be perceived by employees as an increase in bureaucracy, hierarchies, or control. This could trigger behavior that inhibits creative development, and ultimately sustainable PIP [33-35].

\subsection{Creativity}

Creativity can be defined as the production of new ideas about practices, products, or processes that will be of use to organizations for the development of new products or processes [36]. Sternberg and Lubart [37] contend that creativity is the future, as progress is informed by the implementation of a succession of new ideas. Creativity is a rising value within organizations, and a driving force of technological, financial, intellectual, and personal development [38].

This paper is based on creativity at individual level $[18,39,40]$. Along these lines, Csikszentmihalyi [41] has pointed out that the future of individuals and organizations is closely linked to creativity.

From the theoretical perspective of RBV, the generation of competitive advantage relies on the accumulation of strategic resources and capabilities, understood as those imperfectly imitated by competitors [7]. Creativity fulfills these criteria, being considered a dynamic source of competitive advantage, and in this sense, it is of strategic value for firms $[7,8,21,31,42]$.

Creativity is therefore based on the know-how required to make appropriate decisions and create stimuli (information, relationships, motivation, etc.) This may generate alternatives and new sustainable PIP [43]. 


\subsection{Sustainable Product Innovation Performance}

The concept of innovation was introduced by Schumpeter in 1934, alluding to the generation, assimilation, and economic exploitation of a novelty or technical development. Other authors consider innovation to be the introduction of technical change, and it is assumed to be a way of solving problems [24,44-47]. However, other views of innovation understand it to be a set of capabilities or management systems that can be expressed in a final result [48-51].

This paper is based on a particular type of technological innovation, namely, sustainable PIP. According to the OECD [52], product innovation is the "introduction of a new or significantly improved good in terms of its characteristics or its intended use" [53-55]. This definition includes a significant improvement in technical specifications, components and materials, integrated computing, ease of use, and other functional features.

After analyzing three HRs (knowledge, motivation, and relationships) that may be a source of creativity and innovation, this paper focuses exclusively on sustainable PIP. It is considered to be the practical and useful application of a series of new ideas that have been embodied in a final output and serve to satisfy a need, and may therefore be marketable. This type of technological innovation is a material reflection of the efforts made by an organization in matters of HR and creativity. Accordingly, Alegre, Lapiedra, and Chiva [10] argue that PIP encompasses all the material and immaterial efforts a company makes in the management of its resources (efficiency), and the degree to which these efforts are successfully reflected in new product innovation (effectiveness).

The authors are aware that proper HR and creativity management not only lead to good PIP, but also to positive results in other types of technological innovation, such as process innovation or new services.

\subsection{Research Hypotheses}

The impact HR has on sustainable PIP is clearly not independent of context or creativity, among many other variables $[46,56,57]$.

This paper studies creativity as a mediating variable between HR and sustainable PIP. Creativity works as an intervention mechanism between both variables, and it involves an indirect effect that channels a significant part of the relationship between HR and sustainable PIP [58].

This relationship is supported by RBV $[25,26,59]$. In essence, employees will be able to generate environments, routines, and habits in which creativity is developed to a greater extent. Creativity can therefore be considered a dynamic employee capability that the company can materialize in sustainable PIP [60]. To record a good PIP, companies will need highly creative employees with learning patterns and previous technological capabilities.

With a view to ensuring employees develop creative learning patterns, managers need to pay special attention to knowledge, whereby they can use this resource to progress toward their targeted strategic innovation outcome [61]. Employees need to improve and learn from their own experiences, as this will incorporate new knowledge into the organization [62]. Authors such as Pisano [63] argue that not only will coded knowledge be valuable to the organization, but also experiences or failures can help them to develop new capabilities, and therefore new ideas and innovation. An initial research model is now presented with its associated hypotheses.

Model 1. Knowledge-Creativity-Sustainable Product Innovation Performance

Hypothesis 1 (H1). Knowledge positively affects creativity

Hypothesis 2 (H2). Creativity positively affects sustainable PIP

Hypothesis 3 (H3). Creativity has a mediating effect between knowledge and sustainable PIP 
Nevertheless, skills or knowledge are not only important in the process of generating new ideas. This paper states that managers should pay special attention to everything related to employee attitudes and emotions, and therefore motivation [64]. Motivation is the internal force that guides employees' daily behavior toward the achievement of goals. Yet it is not only economic motivation that drives employees in this sense [65]. Authors such as Cohen-Meitar et al. [66] and de Buisonjé et al. [67] argue that creative ideas can be enhanced through a positive mood and self-affirmation [68]. There is therefore another type of internal or intrinsic motivation that will be a true guide for focusing employees' feelings and emotions on stated objectives, such as the generation of new ideas and innovation. There is also evidence to show that creativity-affecting motivation may also lead to intrinsic rewards that are not related to task performance [61]. This type of motivation may be due to internal satisfaction, for example [69,70]. A second research model is now proposed with its associated hypotheses.

Model 2. Motivation-Creativity-Sustainable Product Innovation Performance

\section{Hypothesis 4 (H4). Motivation positively affects creativity}

Hypothesis 5 (H5). Creativity positively affects sustainable PIP

Hypothesis 6 (H6). Creativity has a mediating effect between motivation and sustainable PIP

Finally, managers cannot ignore that employees have emotional ties within the organization. Understanding scientific and technological creativity involves analyzing the interactions between individuals or small groups and their environment [71,72]. These relationships can be driven and directed towards common goals within the organization. Relationships allow employees to pool their ideas and achieve more effective results. Not only are strictly labor (formal) relationships good at achieving common goals, as these relationships are also more effective if they cross organizational boundaries and become strong (informal) ties. A third research model is now proposed with its associated hypotheses:

Model 3. Relationships-Creativity-Sustainable Product Innovation Performance

Hypothesis 7 (H7). Relationships positively affect creativity

Hypothesis 8 (H8). Creativity positively affects sustainable PIP

Hypothesis 9 (H9). Creativity has a mediating effect between relationships and sustainable PIP

Therefore, considering creativity to be an aspect to be honed and developed within the company, it can be argued that those companies that properly manage knowledge, motivation, and relationships help to develop creativity. This means that sustainable PIP is dependent upon creative employees [43,73-75]. Creativity is therefore a mediating variable in the relationship between HR and sustainable PIP. Furthermore, it is relevant to study whether the creativity influenced by the three different antecedents have similar positive impacts on sustainable PIP.

Figure 1 shows the three research models presented here. The present study analyzes three independent models to see the incidence of each of the independent variables on sustainable PIP. In this way, it will be easier for firms to detect in which aspects of HR they should place greater emphasis for sustainable PIP. Therefore, the objective of this study is not to analyze a joint model to see the effects of joint relationships on creativity and sustainable innovation. The objective of this study is to analyze the effects separately in order to clearly and concisely identify on which resource (knowledge, motivation, or relationships) it is necessary to invest in greater measure for the development of sustainable innovations. This approach studies the relationships that may exist in each of the three HR dimensions. Therefore, the models are three, where we test the impact of the three HR dimensions in each model into the same context. 


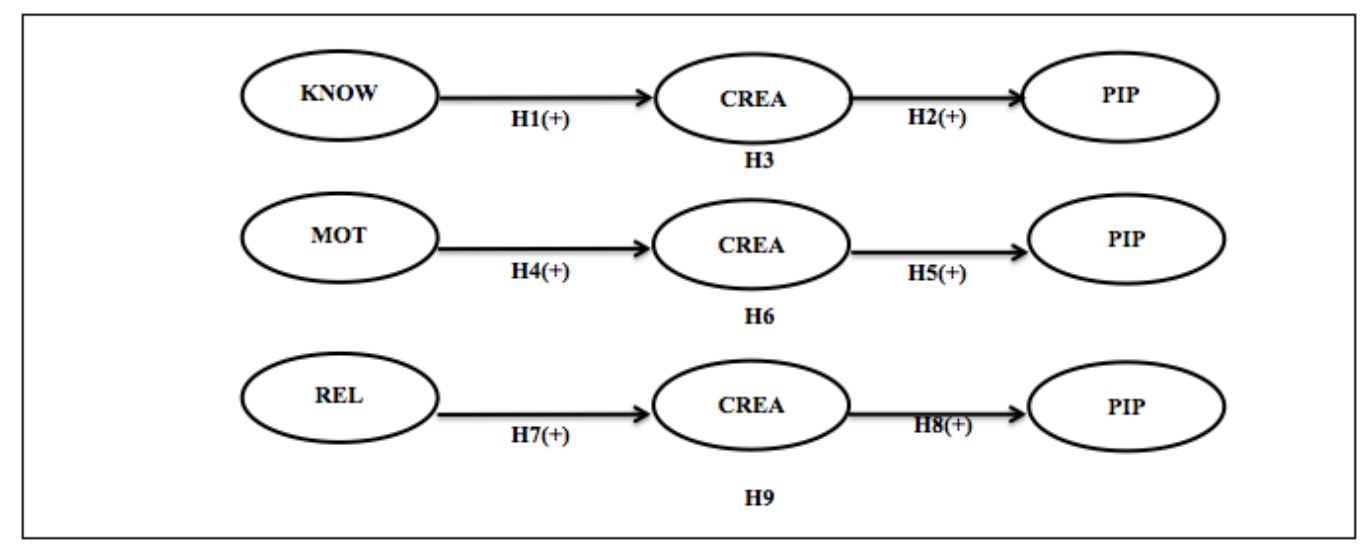

Figure 1. Research models.

\section{Methods}

The paper is based on a multi-sector study by the Center for the Development of Industrial Technology (CDTI in Spanish) of highly innovative companies that have received funding for R\&D projects in the last three years (2016, 2017, and 2018). The information is obtained through an ad-hoc survey and analyzed using SEM.

\subsection{Data and Sample}

The data come from an online survey sent to 1446 certified innovative Spanish SMEs in several industry categories: manufacturing, power, and gas supply; water supply and pollution; building; vehicle trade and repair; transport and storage; catering; information and communication; housing; scientific activities; administrative activities; health activities; and other services. The survey garnered 267 responses. After applying suitable screening procedures [76], the final sample comprises 245 firms, which constitutes a $16.94 \%$ response rate, with a sampling error of $+/-5.7 \%$ at a $95 \%$ confidence level. This is a very adequate response rate for studies of this type.

The survey was managed online through the SurveyMonkey payment platform. An electronic survey was designed to facilitate the work for respondents. Before the survey's final design, a trial was conducted with three prestigious academic experts and five company managers. Once the final survey had been designed, companies were contacted by phone to introduce the study and ask for their e-mails. To minimize the probability of errors due to the interpretation of the language used, the survey was initially drafted in English, and the back-translation method was used for the survey items. Therefore, the questionnaire was originally written in English, translated into Spanish by a certified translator, and then back-translated into English. The survey took $20 \mathrm{~min}$, and the respondents were the CEOs within each firm. CEOs are responsible for making decisions, and they know all of the information and tools required for economic, social, and environmental development. In this sense, CEOs have a realistic and broad vision, and they know the firm's situation for the development of PIP.

Table 1 shows the research's main characteristics.

To check for possible non-response bias, this paper uses a "time trend extrapolation test" in which "late" vs. "early" respondents were compared. The "late" respondents (defined as those responses received after the first round of mailing, i.e., after a follow-up or second mailing) are very similar to non-respondents, given that they would have fallen into that category without the follow-up efforts [77]. A one-way analysis of variance (ANOVA) showed no significant difference between the early and late responses in terms of measures such as firm size (headcount) and firm age. The sample is thus representative of the population. 
Table 1. Research characteristics.

\begin{tabular}{|c|c|}
\hline Population & Innovative Firms \\
\hline Population size & 1446 \\
\hline CNAE-2009 & $\begin{array}{c}01,03,10,11,13,14,15,16,17,18,20,21,22,23,24,25,26,27,28,29,30,31,32, \\
35,36,37,41,42,43,45,46,47,49,52,55,56,58,61,62,63,68,69,70,71,72,73,74,80,82,86,96\end{array}$ \\
\hline Geographical zone and period & Spain between 2016 and 2018 \\
\hline Sample unit & SMEs \\
\hline Respondent & Senior manager \\
\hline Sample size & 245 \\
\hline Response rate & $16.94 \%$ \\
\hline Sample error & $+/-5.7 \%$ \\
\hline Date field work & March-July 2018 \\
\hline Information collection & $\begin{array}{l}\text { Primary sources: On-line survey (SurveyMonkey) } \\
\text { Secondary sources: CDTI and SABI } \rightarrow \text { Own Database in PHP }\end{array}$ \\
\hline Statistical packages & SPSS 23 and AMOS 23 \\
\hline
\end{tabular}

Note. CNAE = Clasificación Nacional de Actividades Económicas; CDTI = Centro para el Desarrollo Tecnológico Industrial; SABI = Sistema de Análisis de Balances Ibéricos.

\subsection{Measures}

The constructs' items are measured using a Likert-type scale that ranges from 1 (strongly disagree) to 7 (strongly agree). The three models overall have a structure with five constructs that comprise knowledge (KNOW), motivation (MOT), relationships (REL), creativity (CREA), and sustainable product innovation performance (PIP).

Knowledge (KNOW) is measured using a scale of eight items in two orientations (four items for tacit knowledge and four items for explicit knowledge) [78-80].

Motivation (MOT) is measured using a scale of fourteen items between its two orientations (eight for intrinsic motivation and six for extrinsic motivation) [69,81,82].

Relationships (REL) is measured using a scale of ten items between its two orientations (six for informal relationships and four for formal relationships) [69,83-87].

Creativity (CREA) is measured through the TTCT, using a six-item scale $[18,88,89]$. The TTCT comprise various tasks with verbal and figurative content designed to estimate the level of creativity according to the dimensions or cognitive functions of fluency, flexibility, originality, and elaboration of employees' ideas. This is a relevant tool for measuring employee creativity in the field of management $[19,90]$.

The composition of these measures may be of particular interest for future research. They also reflect more internal and informal employee aspects (wishes, emotions, ideas, or feelings) from an ambidextrous perspective, which compounds the difficulty of their measurement. The measures support a conceptual differentiation between the two types of knowledge, two types of motivation, and two types of relationships [69].

Finally, sustainable PIP is measured using a scale of three items [46,81,90-93].

This paper begins by focusing on Creativity as an antecedent of sustainable PIP. In addition, sustainable PIP is the most visible form of innovation for clients and will lead companies to obtain greater benefits more directly $[10,94]$.

The paper also performs a confirmatory factor analysis (CFA) using AMOS $^{\circledR}$ to assess measurement validity. The paper retains the 50 items that meet the recommended levels [95] indicating good measurement validity. The unidimensionality among the items in each variable is confirmed [76].

Table 2 shows factorial loads, variance explained, and Cronbach's alpha [76].

Table 2. Item and loading factor.

Loading Factor

Knowledge $(\mathrm{KNOW})(\mathrm{V} . \mathrm{E}=64.36 \%)$

Explicit knowledge (EX_KNOW) $(\alpha=0.76)$

EX1_KNOW. In my organization, employees receive support for training spending 
Table 2. Cont.

\begin{tabular}{|c|c|}
\hline & Loading Factor \\
\hline EX2_KNOW. In my organization, employees receive training & 0.64 \\
\hline EX3_KNOW. In my organization, employees receive support to obtain high qualifications & 0.76 \\
\hline EX4_KNOW. My organization provides support for obtaining information in databases and intranet & 0.83 \\
\hline EX5_KNOW. My organization provides support regarding information in a finished product & 0.62 \\
\hline \multicolumn{2}{|l|}{ Tacit knowledge (TA_KNOW) $(\alpha=0.78)$} \\
\hline TA6_KNOW. My organization supports the employees' experience & 0.77 \\
\hline TA7_KNOW. My organization supports the employees' abilities & 0.79 \\
\hline TA8_KNOW. My organization supports interdisciplinary training & 0.74 \\
\hline TA9_KNOW. My organization supports practical courses & 0.77 \\
\hline \multicolumn{2}{|l|}{ Motivation (MOT) $(\mathrm{V} . \mathrm{E}=65.67 \%)$} \\
\hline \multicolumn{2}{|l|}{ Extrinsic Motivation (EXT_MOT) $(\alpha=0.85)$} \\
\hline EXT1_MOT. In my organization, people receive a good wage & 0.67 \\
\hline EXT2_MOT. In my organization, there is equal pay & 0.6 \\
\hline EXT3_MOT. In my organization, there is individual compensation & 0.77 \\
\hline EXT4_MOT. In my organization, there is group compensation & 0.82 \\
\hline EXT5_MOT. In my organization, there is business compensation & 0.8 \\
\hline EXT6_MOT. In my organization, there is job flexibility & 0.63 \\
\hline EXT7_MOT. In my organization, there is conciliation & 0.68 \\
\hline EXT8_MOT. In my organization, there is promotion & 0.73 \\
\hline \multicolumn{2}{|l|}{ Intrinsic Motivation (INT_MOT) $(\alpha=0.94)$} \\
\hline INT9_MOT. In my organization, the employees have satisfaction & 0.8 \\
\hline INT10_MOT. In my organization, the employees have engagement & 0.9 \\
\hline INT11_MOT. In my organization, the employees have responsibility & 0.85 \\
\hline INT12_MOT. In my organization, the employees have identification & 0.9 \\
\hline INT13_MOT. In my organization, the employees have consideration about problems & 0.71 \\
\hline INT14_MOT. In my organization, the employees have trust & 0.89 \\
\hline INT15_MOT. In my organization, the employees have implication & 0.88 \\
\hline INT16_MOT. In my organization, the employees have self-realization & 0.76 \\
\hline \multicolumn{2}{|l|}{ Relationships (REL) (V.E $=62.22 \%$ ) } \\
\hline \multicolumn{2}{|l|}{ Formal Relationships (FOR_REL) $(\alpha=0.88)$} \\
\hline FOR1_REL. In my organization, there are software programs and databases & 0.66 \\
\hline FOR2_REL. In my organization, there are business meetings & 0.66 \\
\hline FOR3_REL. In my organization, the customers are a source of information & 0.69 \\
\hline FOR4_REL. In my organization, the suppliers are a source of information & 0.86 \\
\hline FOR5_REL. In my organization, the allies are a source of information & 0.74 \\
\hline FOR6_REL. In my organization, there is teamwork & 0.67 \\
\hline FOR7_REL. In my organization, there is work with customers & 0.72 \\
\hline FOR8_REL. In my organization, there is work with suppliers & 0.82 \\
\hline FOR9_REL. In my organization, there is work with allies & 0.63 \\
\hline \multicolumn{2}{|l|}{ Informal Relationships (INFOR_REL) $(\alpha=0.90)$} \\
\hline INFOR10_REL. In my organization, there are relaxed meetings & 0.77 \\
\hline INFOR11_REL. In my organization, there are discussions & 0.82 \\
\hline INFOR12_REL. In my organization, there are coincidences & 0.82 \\
\hline INFOR13_REL. In my organization, there are common spaces (offices) & 0.69 \\
\hline INFOR14_REL. In my organization, there is consensus & 0.76 \\
\hline INFOR15_REL. In my organization, there is cooperation & 0.82 \\
\hline \multicolumn{2}{|l|}{ Creativity $(\mathrm{CREA})(\mathrm{V} . \mathrm{E}=75.09 \%) ;(\alpha=0.94)$} \\
\hline CREA1. In my organization, people receive support for curiosity and pro-activity & 0.9 \\
\hline CREA2. In my organization, people receive support and encouragement when presenting new ideas & 0.91 \\
\hline CREA3. In my organization, there are various solutions & 0.87 \\
\hline CREA4. In my organization, there are infrequent solutions & 0.88 \\
\hline CREA5. In my organization, there is care, detail and production & 0.79 \\
\hline CREA6. In my organization, there is spontaneity and improvisation & 0.85 \\
\hline CREA7. In my organization, there is energy and vitality & 0.83 \\
\hline \multicolumn{2}{|l|}{ Sustainable Product Innovation Performance (PIP) (V.E $=73.69 \%) ;(\alpha=0.68)$} \\
\hline PIP1. Number of innovation in sustainable product & 0.78 \\
\hline PIP2. Sales of new sustainable product & 0.82 \\
\hline PIP3. New Sustainable Products comparison with portfolio products & 0.74 \\
\hline
\end{tabular}




\section{Results}

\subsection{SEM Analysis and Results}

The paper uses SEM to test the data fit for the three models (H1-H9). This approach aims to define latent variables, and then establish causal relationships. A common norm in the literature for the application of SEM indicates a minimum sample of 100 [96]. This paper is based on a total of 245 companies, so it is well above the established requirement.

The fit indexes show an adequate overall model fit. Table 3 presents the absolute $\left(x^{2} / \mathrm{df}, \mathrm{RMSEA}\right)$ and incremental (CFI, TLI) indexes that factor in the values recommended by Hair et al. [76] and Byrne [97] for a good measurement model fit and for a good structural model fit.

Table 3. Measurement model fit and structural model fit.

\begin{tabular}{cccccccc}
\hline Measurement Models Fit & $\mathbf{X}^{\mathbf{2}}$ & $\mathbf{D f}$ & $\boldsymbol{p}$-Value & $\mathbf{X}^{\mathbf{2}} / \mathbf{d f}$ & $\mathbf{C F I}$ & TLI & RMESA \\
\hline KNOW-CREA-PIP & 38.424 & 17 & 0.000 & 2.260 & 0.970 & 0.937 & 0.072 \\
MOT-CREA-PIP & 246.134 & 89 & 0.000 & 2.766 & 0.950 & 0.932 & 0.070 \\
REL-CREA-PIP & 213.589 & 79 & 0.000 & 2.704 & 0.948 & 0.931 & 0.070 \\
\hline Structural Models Fit & $\mathbf{X}^{\mathbf{2}}$ & $\mathbf{D f}$ & $\boldsymbol{p}$-Value & $\mathbf{X}^{\mathbf{2}} / \mathbf{d f}$ & $\mathbf{C F I}$ & TLI & $\mathbf{R M E S A}$ \\
\hline KNOW-CREA-PIP & 543.751 & 148 & 0.000 & 3.674 & 0.894 & 0.862 & 0.071 \\
MOT-CREA-PIP & 1089.282 & 296 & 0.000 & 3.680 & 0.874 & 0.872 & 0.071 \\
REL-CREA-PIP & 1032.350 & 272 & 0.000 & 3.795 & 0.873 & 0.880 & 0.077 \\
\hline
\end{tabular}

Note. $\mathrm{KNOW}=$ Knowledge; MOT $=$ Motivation; REL $=$ Relationships; CREA = Creativity; PIP = Sustainable Product Innovation Performance; $X^{2}=$ Chi-squared; Df = Degrees of Freedom; CFI = Comparative Fit Index; TLI = Tucker-Lewis Index; RMSEA = Root Mean Squared Error of Approximation.

\subsection{Measurement Model Fit}

The study assesses the overall fit of the measurement model following the guidelines reported by Hair et al. [76] that uses CFA to assess the psychometric properties of constructs. The first- and second-order confirmatory test with multiple factors shows an adequate fit (Table 2).

The results obtained in the measurement model fit are shown below.

For the first measurement model fit (Knowledge-Creativity-Sustainable Product Innovation Performance), a $\chi^{2}$ of 38.424 (degrees of freedom $=17, p=0.000$ ) is obtained, with a $\chi^{2} / \mathrm{df}$ of 2.260, which is less than 3.0. Jöreskog and Sörbom [98] posit that this value should be between 0 and 3 for the model to present a good fit. The Comparative Fit Index (CFI) is 0.970, and the Tucker-Lewis Index (TLI) is 0.937. These indexes are above 0.9 , indicating a good fit. The next statistical value is Root Mean Square Error of Approximation (RMSEA). This value is 0.072 , less than 0.08 , thereby indicating a good fit. Browne and Cudeck [99] contend that values below 0.08 indicate a good fit, and values over 0.08 represent reasonable approximation errors in the population.

In the second measurement model fit (Motivation-Creativity-Sustainable Product Innovation Performance), $\chi^{2}$ is 246.134 (degrees of freedom $=89, p=0.000$ ) and $\chi^{2} / \mathrm{df}$ is 2.766 . The CFI is 0.950 , TLI is 0.932 , and RMSEA is 0.070 . This model also presents a good fit.

In the third measurement model fit (Relationships-Creativity-Sustainable Product Innovation Performance), $\chi^{2}$ is 213.589 (degrees of freedom $=79, p=0.000$ ) and $\chi^{2} / \mathrm{df}$ is 2.704. The CFI is 0.948, TLI is 0.931, and RMSEA is 0.070. As in the two previous measurement model fits, this model also presents a good fit.

All three measurement models have good fit, indicating that all the constructs have been correctly measured. 


\subsection{Structural Model Fit}

Tables 3 and 4 show the main results obtained in the structural model fit. Table 3 shows the results obtained in the measurement model fit, and Table 4 shows the results obtained in the structural model fit used to test the hypotheses (H1-H9).

Table 4. Research hypotheses and results.

\begin{tabular}{|c|c|c|c|c|c|c|}
\hline KNOW-CREA-PIP & Causal Relations & Estimator & SE & CR & $p$-Value & Results \\
\hline $\mathrm{H} 1(+)$ & $\mathrm{CREA} \leftarrow \mathrm{KNOW}$ & 1.762 & 0.454 & 3.879 & $* * *$ & Supported \\
\hline $\mathrm{H} 2(+)$ & $\mathrm{PIP} \leftarrow \mathrm{CREA}$ & 0.533 & 0.085 & 6.265 & $* * *$ & Supported \\
\hline $\mathrm{H} 3(+)$ & $\mathrm{PIP} \leftarrow \mathrm{CREA} \leftarrow \mathrm{KNOW}$ & - & - & - & - & Supported \\
\hline Total Mediation: & $\begin{array}{c}\mathrm{TE}=\mathrm{DE}+\mathrm{IE}=0.000+(0.845 \times \\
0.525)=0.444\end{array}$ & & & & & \\
\hline MOT-CREA-PIP & Causal relations & Estimator & SE & CR & $p$-Value & Results \\
\hline $\mathrm{H} 4(+)$ & $\mathrm{CREA} \leftarrow \mathrm{MOT}$ & 0.377 & 0.049 & 7.729 & $* * *$ & Supported \\
\hline $\mathrm{H} 5(+)$ & $\mathrm{PIP} \leftarrow$ CREA & 0.520 & 0.093 & 5.564 & $* * *$ & Supported \\
\hline $\mathrm{H} 6(+)$ & $\mathrm{PIP} \leftarrow \mathrm{CREA} \leftarrow \mathrm{MOT}$ & - & - & - & - & Supported \\
\hline Total Mediation: & $\mathrm{TE}=0.000+(0.499 \times 0.475)=0.237$ & & & & & \\
\hline REL-CREA-PIP & Causal relations & Estimator & SE & CR & $p$-Value & Results \\
\hline $\mathrm{H7}(+)$ & $\mathrm{CREA} \leftarrow \mathrm{REL}$ & 0.140 & 0.042 & 3.331 & $* * *$ & Supported \\
\hline $\mathrm{H} 8(+)$ & $\mathrm{PIP} \leftarrow \mathrm{CREA}$ & 0.524 & 0.090 & 5.812 & $* * *$ & Supported \\
\hline $\mathrm{H} 9(+)$ & $\mathrm{PIP} \leftarrow \mathrm{CREA} \leftarrow \mathrm{REL}$ & - & - & - & - & Supported \\
\hline
\end{tabular}

Mediation: $\quad \mathrm{TE}=0.000+(0.806 \times 0.499)=0.398$

Note. $\mathrm{KNOW}=$ Knowledge; $\mathrm{MOT}=$ Motivation; REL $=$ Relationships; CREA = Creativity; PIP = Sustainable Product Innovation Performance; $\mathrm{SE}=$ Standard Error; $\mathrm{CR}=$ Composite Reliability; ${ }^{* * *}=p<0.001 ; \mathrm{TE}=$ Total Effect; DE = Direct Effect; IE = Indirect Effect.

The first proposed structural model fit (Knowledge-Creativity-Sustainable Product Innovation Performance) analyzes H1, H2, and H3.

$\mathrm{H} 1$ explains the relationship between knowledge and creativity. The results confirm a significant effect between knowledge and creativity with $\beta=1.762(p<0.001)$. Knowledge has positive and significant effects on creativity. $\mathrm{H} 1$ is therefore supported by the results obtained in the first structural model fit.

$\mathrm{H} 2$ explains the relationship between creativity and sustainable PIP. This hypothesis is replicated in the following two models (H5 and H8). There is a need to study the effects of mediation between variables in the three models proposed. In this case, the first structural model fit confirms a significant effect between creativity and sustainable PIP with $\beta=0.533$ $(p<0.001)$. Creativity affects sustainable PIP in a positive and significant way. $\mathrm{H} 2$ is thus supported by the results obtained in the first structural model fit.

$\mathrm{H} 3$ indicates that creativity mediates between knowledge and sustainable PIP. The results confirm the existence of total mediation by introducing creativity between knowledge and sustainable PIP, with creativity channeling the total effect of knowledge on sustainable PIP. As shown in the results, the total effect (0.444) when introducing creativity is equal to the indirect effect $(0.845 \times 0.525)$, canceling the direct effect $(0.000)$ initially exerted by knowledge on sustainable PIP. Therefore, and according to the results obtained in this first structural model fit, $\mathrm{H} 3$ is supported.

The second structural model fit (Motivation-Creativity-Sustainable Product Innovation Performance) studies H4, H5, and H6.

$\mathrm{H} 4$ explains the relationship between motivation and creativity. The results confirm a significant effect between motivation and creativity with $\beta=0.377(p<0.001)$. Motivation affects creativity positively and significantly. $\mathrm{H} 4$ is therefore supported by the results obtained in the second structural model fit proposed.

$\mathrm{H} 5$ analyzes the relationship between creativity and sustainable PIP within this model. In this case, too, the results confirm a positive and significant effect between creativity and 
sustainable PIP with $\beta=0.520(p<0.001)$, as in the previous model. H5 is therefore also confirmed by the results obtained in the second structural model fit analyzed.

$\mathrm{H} 6$ proposes that creativity is a mediating variable between motivation and sustainable PIP. The results also confirm the existence of total mediation, which means that when creativity is introduced between motivation and sustainable PIP, creativity channels motivation's total effect on sustainable PIP. The total effect $(0.237)$ when introducing creativity is the same as the indirect effect $(0.499 \times 0.475)$, canceling the direct effect $(0.000)$ that motivation would initially have on sustainable PIP. Therefore, and according to the results obtained in the second structural model fit, $\mathrm{H} 6$ is supported.

The third structural model fit (Relationships-Creativity-Sustainable Product Innovation Performance) analyzes H7, H8, and H9.

$\mathrm{H} 7$ analyzes the possible relationship between relationships and creativity. The results confirm a significant effect between relationships and creativity with $\beta=0.140(p<0.001)$. Employee relationships have a positive and significant effect on creativity. H7 is supported by the results obtained in this third structural model fit.

H8 studies the relationship between creativity and sustainable PIP within this model. The results here again confirm a positive and significant effect between creativity and sustainable PIP with $\beta=0.524(p<0.001)$, as in the two previous models. H8 is again supported.

Finally, $\mathrm{H} 9$ analyzes creativity's mediating role between relationships and sustainable PIP. The results again support the existence of this mediating effect. The total effect (0.398) when introducing creativity is the same as the indirect effect $(0.806 \times 0.499)$, canceling the direct effect $(0.000)$ that relationships initially exerted on sustainable PIP. H9 is therefore supported by the results obtained in this third structural model fit.

The research results provide relevant information when confirming in the three models (knowledge, motivation, and relationships) that creativity positively affects sustainable PIP, that is, $\mathrm{H} 2, \mathrm{H} 5$, and $\mathrm{H} 8$ are confirmed. This finding reveals the importance of creativity in each model, clearly becoming a mediating variable and always an antecedent of sustainable PIP.

Therefore, the results confirm that when managers properly orient HR (knowledge, motivation, and relationships) they will boost the development of new ideas (creativity), and ultimately sustainable PIP. This paper highlights the importance of creativity for sustainable PIP, and therefore for achieving a sustainable competitive advantage. Our main finding supported by the three structural model fits is the mediating role creativity plays between HR and sustainable PIP. Creativity is a variable that channels the influence of HR on sustainable PIP, whereby managers may prompt their employees to develop more ideas. These ideas will strengthen sustainable PIP.

Table 4 shows that the three structural model fits are adequate. These results are briefly discussed below.

In the first structural model fit (Knowledge-Creativity-Sustainable Product Innovation Performance), $\chi^{2}$ is 543.751 (degrees of freedom $=148, p=0.000$ ), and $\chi^{2} / \mathrm{df}$ has a value of 3.674, which is not much higher than 3.0 [98]. The CFI is 0.894 , and the TLI is 0.862 . These scores are close to 0.9 , indicating a good fit. The RMSEA is 0.071 , less than 0.08 , indicating a good fit [99].

In the second structural model fit (Motivation-Creativity-Sustainable Product Innovation Performance), $\chi^{2}$ is 1089.282 (degrees of freedom $=296, p=0.000$ ), and $\chi^{2} / \mathrm{df}$ has a value of 3.680 , a value fairly close to 3.0 [98]. The CFI is 0.874 , and the TLI is 0.872 . Ratings close to 0.9 indicate a good fit. The RMSEA is 0.071 , indicating a good fit [99].

Finally, in the third structural model fit analyzed here (Relationships-CreativitySustainable Product Innovation Performance), $\chi^{2}$ is 1032.350 (degrees of freedom $=272$, $p=0.000$ ) and $\chi^{2} / \mathrm{df}$ has a value of 3.795 [98]. The CFI is 0.873 and the TLI is 0.880 . The RMSEA is 0.077 [99]. The three structural models record a good joint fit in the final results. 


\section{Discussion and Conclusions}

The paper is based on three structural equation models for predicting the effects of knowledge, motivation, and relationships on creativity and sustainable product innovation performance. Considering this quantitative method of data analysis, the models reveal important findings. First, knowledge, motivation, and relationships have a positive and significant effect on creativity (H1, H4, and H7, respectively). These three types of HR therefore allow developing more ideas. Second, the models show that creativity has a positive and significant effect on sustainable PIP ( $\mathrm{H} 2, \mathrm{H} 5$ and $\mathrm{H} 8$, respectively). Thus, creativity leads to the greater success of sustainable PIP. This finding shows two important conclusions: (a) Regardless of the HR management model chosen by the manager (knowledge, motivation, and relationships), creativity must be managed and developed in its employees for the development of sustainable PIP. Creativity will always have a positive effect on sustainable PIP regardless of whether it is generated by managing the factors of knowledge, motivation or relationships; (b) Methodologically, this finding shows the consistency and robustness of the models by precisely obtaining a positive effect between creativity and sustainable PIP in the three models studied separately. The results obtained show that creativity is always an antecedent variable of sustainable PIP regardless of the choice of the HR model. The study reveals that the importance is that each model develops the key success factors for the development of creativity and, consequently, sustainable PIP.

Third, creativity acts as a mediating variable, channeling all the effects of HR (knowledge, motivation, and relationships) on sustainable PIP (H3, H6, and $\mathrm{H} 9$, respectively). This is one of the article's main contributions.

This research focused on the impact of the HR elements (knowledge, motivation, and relationships) on creativity and sustainable PIP. In addition, it is very interesting to see the detailed on the results of the factors of HR and their impact on creativity (thus sustainable PIP). In this line, the results show that the factors of both dimensions of knowledge (explicit knowledge and tacit knowledge) are relevant to explaining creativity and, therefore, sustainable innovation. However, it is important to note that within the explicit knowledge dimension, factors such as employee qualification and having comprehensive technological management, data storage, and software systems contribute highly to the development of creativity and sustainable innovation. The use of integral management systems (intranet) not only contributes to the storage of relevant information for companies but it also contributes to sustainable development by eliminating inefficient management practices in companies such as the use and storage of paper. On the other hand, the factors associated with tacit knowledge (experience, abilities, training, and practical courses) have a great impact on the development of new ideas and, therefore, on sustainable innovation.

The results show that the factors of both dimensions of motivation (extrinsic knowledge and intrinsic motivation) are relevant to explain creativity and, therefore, sustainable innovation. Although it is important to note that within the extrinsic motivation dimension, factors such as group incentives contribute greatly to the development of creativity and sustainable innovation. On the other hand, the factors associated with intrinsic motivation (satisfaction, commitment, responsibility, identification and consideration of problems) have a great impact on the development of new ideas and, therefore, on sustainable innovation.

The results show that the factors of both dimensions of relationships (formal relationships and informal relationships) are relevant to explain creativity and, therefore, sustainable innovation. However, it is important to note that within the formal relationships dimension, factors such as stakeholder relationships (suppliers, customers, and other allies) contribute greatly to the development of creativity and sustainable innovation. On the other hand, the factors associated with informal relationships (meetings, cooperation, or common spaces or offices) have a great impact on the development of new ideas and, therefore, on sustainable innovation.

These findings broaden our knowledge about HR and sustainable PIP, showing that creativity plays a key role in new product development. Sustainable PIP is considered 
a type of innovation capable of focusing management efforts and successful innovation. This finding is reinforced in the three research models proposed, whose variables have taken into account two different organizational levels (individual level and organizational level) [5].

In sum, the results reveal the key role managers have to play to turn knowledge, motivation, and relationships into creative ideas and sustainable PIP. All the hypotheses tested in the three research models are confirmed, with special emphasis on the fact that creativity is able to channel all the effects of the three resources, and directly and indirectly affect sustainable PIP $[40,100]$. Our results show that knowledge, motivation, and relationships have similar positive impacts on sustainable PIP (via creativity), thus we propose they are alternative foundations of creativity that support sustainable PIP.

Based on three structural equation models, this paper confirms the possible alternatives (knowledge, motivation, and relationships) for developing human talent within the company, and how it can be oriented toward sustainable PIP [101]. The three models agree in that creativity is now a cornerstone within companies [102]. Managers will be the ones to direct, manage, and motivate human talent within organizations to generate new ideas and sustainable PIP.

\section{Limitations and Future Research}

In addition, the paper reveals considerable potential for the analytical exploitation of data for future research. The models presented have orientations of knowledge (tacit/explicit), motivation (intrinsic/extrinsic), and relationships (informal/formal). This could also lead to important findings, identifying the type of knowledge, motivation and relationships with a greater impact on creativity and, consequently, on sustainable PIP. In this vein, this paper makes an important contribution, laying the foundations for a new tool for the complete measurement of HR. As a measure of HR variables, there are not only more explicit, extrinsic, and formal employee aspects, gathered largely by previous literature, but also more internal HR aspects (tacit, intrinsic, and informal). This adds value to the scale of metrics used in this paper by including some aspects of variables that are very difficult to measure.

Another aspect to be taken into account in future research is that these three models could be unified to consider the impact of the HR dimensions jointly in one complete and unique model. This approach could study new relationships and synergies that may exist between the three HR dimensions (knowledge, motivation, and relationships). In addition, the model could add other types of technological innovation, such us process innovations or, from another point of view, radical and incremental innovations. It would lead to complete structural equation modeling with variables at different organizational levels.

The paper uses an advanced quantitative approach SEM to test the hypotheses, thus catering for the study of more complex causal relationships. It may also be convenient to use another qualitative approach to data. The fuzzy-set Qualitative Comparative Analysis (fsQCA) is a new statistical technique that establishes different paths between variables or causal configurations that provide results in matters of creativity and sustainable PIP [103-105]. Therefore, by introducing this second qualitative data analysis technique, the paper would use a mixed-method design in its methodology [106]. This could be considered a relevant contribution, and would help to provide new conclusions on the study of creativity and sustainable PIP $[107,108]$.

The paper is based on a representative sample of highly innovative Spanish companies over three recent years (2016, 2017, and 2018). It may be considered a longitudinal study involving part of the population or universe of Spanish innovative companies and the changes they have undergone over the three years analyzed. It would nonetheless be expedient to gather the information again after another three years (as from the approval of the public funds), and thus provide new evidence. Future research should seek out and discover novel approaches to human talent management to help improve creativity and sustainable PIP within firms. 


\section{Practical Implications}

Given the lack of academic papers that analyze the aspects this study addresses, it is particularly important that the conclusions from this multidisciplinary research should contribute empirical evidence.

This study highlights the importance of having suitable HR (knowledge, motivation, and relationships) in order to achieve the utmost creative performance, and consequently obtain more novel and useful ideas for their subsequent development or introduction by any firm.

First, the study notes the importance of having employees with suitable skills for generating more knowledge and, consequently, the highest possible number of creative ideas. Employees should be individuals with specific skills for creative thinking and with a high intrinsic motivation. Moreover, a key element for supporting intrinsic motivation (essential for creativity) is the provision of challenging tasks in which employees have to implement their own capabilities and skills. In this sense, it is important for a firm to have different types of employees with different individual characteristics, with the aim of maximizing the use of their creative potential. In addition, employee relationships can improve creative thinking and, consequently, sustainable PIP.

In sum, the results reveal the key role managers have to play to turn knowledge, motivation, and relationships into creative ideas and sustainable PIP. In this line, managers must make a continuous investment in factors of tacit knowledge (experience, abilities, training, and practical courses) [109-115], factors of intrinsic motivation [116-118] (satisfaction, commitment, responsibility, identification and consideration of problems) and factors of informal relationships [119] (meetings, cooperation or common spaces or offices) without neglecting certain factors associated with explicit knowledge (employee qualification and databases and intranet), extrinsic motivation (group incentives), and formal relationships (stakeholders relationships: suppliers, customers and other allies) if they want to maintain a sustainable competitive advantage through creativity and PIP.

In addition, in recent years, one of the key issues addressed by sustainable development is based on the relationship between business innovation and sustainability. Today this relationship is gaining even more strength in order to mitigate the risk associated with the Covid-19 crisis and even take advantage of it as a lever to boost its activity in a renewed and sustainable way. Consequently, sustainable innovations represent an important means through which organizations can promote sustainable development. At the same time, current challenges can become a source of inspiration that can improve the competitiveness of companies and contribute to the construction of a better society.

Furthermore, innovation requires a "group" approach in which different stakeholders (such as employees, customers, suppliers, and governments) are involved. For this reason, the management of HR is very important. On the one hand, the participation of interested parties helps to clarify the criteria and subsequently to operationalize new innovation strategies. A clear example today is the development of the vaccine against Covid-19. Innovation is currently being developed in SMEs around the world with knowledge, motivation, and relationship of all employees [120-123]. Faced with the current economic and health crisis caused by Covid-19, companies are using their highest levels of innovation and HR to adapt and develop new materials and medical devices in record time, achieving compatibility through the invisible hand of their own legitimate economic interests with the enormous social interests that this field of work entails. If we go one step further and ensure that innovation and HR cross borders, we can also achieve broader results, such as the development of a new treatment against Covid-19 or the creation of a new vaccine $[124,125]$.

Additionally, most firms' innovation efforts are focused on only one development goal at a time, and research has yet to provide an in-depth discussion on how to more powerfully link the goal of sustainability and HR in the dynamic of innovation [126,127]. 
Author Contributions: Conceptualization, L.M.-P., J.G., and C.C.; methodology, L.M.-P., J.G., and C.C.; software, L.M.-P.; validation, L.M.-P., J.G., and C.C.; formal analysis, L.M.-P.; investigation, L.M.-P., J.G., and C.C.; data curation, L.M.-P.; writing-original draft preparation, L.M.-P.; writingreview and editing, L.M.-P., J.G., and C.C.; visualization, L.M.-P., J.G., and C.C.; supervision, J.G. and C.C.; project administration, J.G. and C.C.; funding acquisition, L.M.-P., J.G., and C.C. All authors have read and agreed to the published version of the manuscript.

Funding: The authors are grateful for the economic support provided by FCT (Fundação para a Ciência e Tecnologia Portugal) grant number UIDB/04521/2020, by "Agencia Estatal de Investigación" (AEI) of the Ministerio de Ciencia e Innovación del Gobierno de España grant number PID2019-107546GA-I00, by Consejería de Educación of the Junta de Castilla y León and the "Fondo Europeo de Desarrollo Regional" (FEDER) grant number SA106P20, and by Junta de Castilla y León and the European Regional Development Fund for the financial support to the Research Unit of Excellence “Economic Management for Sustainability" (GECOS) grant number CLU-2019-03.

Institutional Review Board Statement: Not applicable.

Informed Consent Statement: Not applicable.

Conflicts of Interest: The authors declare no conflict of interest.

\section{References}

1. Duncan, R.B. The ambidextrous organization: Designing dual structures for innovation. In The Management of Organization Design: Strategies and Implementation; Kilmann, R.H., Pondy, L., Slevin, R.D., Eds.; North Holland: New York, NY, USA, 1976; pp. 167-188.

2. Eisenhardt, K.M.; Martin, J.A. Dynamic capabilities: What are they? Strateg. Manag. 2000, 21, 1105-1121. [CrossRef]

3. Raisch, S.; Birkinshaw, J. Organizational ambidexterity: Antecedents, outcomes, and moderators. J. Manag. $2008,34,375-409$. [CrossRef]

4. Caniëls, M.C.J.; Kronenberg, K.; Werker, C. Conceptualizing proximity in research collaborations between universities and firms. In The Social Dynamics of Innovation Networks; Rutten, R., Benneworth, P., Irawati, D., Boekema, F., Eds.; Routledge: Abingdon, UK, 2014; pp. 221-238.

5. Lo, F.Y. Factors leading to foreign subsidiary ownership: A multi-level perspective. J. Bus. Res. 2016, 69, 5228-5234. [CrossRef]

6. Wernerfelt, B. A resource-based view of the firm. Strateg. Manag. J. 1984, 5, 171-180. [CrossRef]

7. Barney, J.B. Firm resources and sustained competitive advantage. J. Manag. 1991, 17, 99-120. [CrossRef]

8. Barney, J.B. Looking inside for competitive advantage. Acad. Manag. Exec. (1993-2005) 1995, 9, 49-61. [CrossRef]

9. Peteraf, M.A. The cornerstones of competitive advantage: A resource based view. Strateg. Manag. J. 1993, 14, 179-191. [CrossRef]

10. Alegre, J.; Lapiedra, R.; Chiva, R. A measurement scale for product innovation performance. Eur. J. Innov. Manag. 2006, 9, 333-346. [CrossRef]

11. De Visser, M.; Faems, D. Exploration and exploitation within firms: The impact of CEOs' cognitive style on incremental and radical innovation performance. Creat. Innov. Manag. 2015, 24, 359-372. [CrossRef]

12. Marín-Idárraga, D.A.; Hurtado González, J.M.; Cabello Medina, C. The antecedents of exploitation-exploration and their relationship with innovation: A study of managers' cognitive maps. Creat. Innov. Manag. 2016, 25, 18-37. [CrossRef]

13. Agostini, L.; Filippini, R.; Nosella, A. Towards an integrated view of the ambidextrous organization: A second-order factor model. Creat. Innov. Manag. 2016, 25, 129-141. [CrossRef]

14. Zacher, H.; Robinson, A.J.; Rosing, K. Ambidextrous leadership and employees'self-reported innovative performance: The role of exploration and exploitation behaviors. J. Creat. Behav. 2016, 50, 24-46. [CrossRef]

15. Levinthal, D.A.; March, J.G. The myopia of learning. Strateg. Manag. 1993, 14, 95-112. [CrossRef]

16. Gratton, L.; Ghoshal, S. Managing personal human capital: New ethos for the volunteer' employee. Eur. Manag. J. 2003, 21, 1-10. [CrossRef]

17. Gu, J.; Zhang, Y.; Liu, H. Importance of social capital to student creativity within higher education in China. Think. Ski. Creat. 2014, 12, 14-25. [CrossRef]

18. Torrance, E.P. The Torrance Tests of Creative Thinking-Norms-Technical Manual Research Edition-Verbal Tests, Forms A and B-Figural Tests, Forms A and B; Personnel Press: Princeton, NJ, USA, 1974.

19. Yoon, C.-H. A validation study of the Torrance Tests of Creative Thinking with a sample of Korean elementary school students. Think. Ski. Creat. 2017, 26, 38-50. [CrossRef]

20. Long, H. An empirical review of research methodologies and methods in creativity studies (2003-2012). Creat. Res. J. 2014, 26, 427-438. [CrossRef]

21. Grant, R.M. The resource-based theory of competitive advantage: Implications for Strategy. Calif. Manag. Rev. 1991, $33,114-135$. [CrossRef]

22. Spender, J.C. Knowledge and the firm: Overview. Strateg. Manag. J. 1996, 17, 5-9. [CrossRef]

23. Teece, D.J. Strategies for managing knowledge assets: The role of firm structure and industrial context. Long Range Plan. 2000, 33, 35-54. [CrossRef] 
24. March, J.G.; Simon, H.A. Organizations; Willey: Oxford, UK, 1958.

25. Foss, N. The Resource-Based Perspective: An assessment and diagnosis of problems. Scand. J. Manag. 1998, 14, 133-149. [CrossRef]

26. Langlois, R.; Robertson, P. Empresas, Mercados Y Cambio Económico; Biblioteca Episteme: Barcelona, Spain, 2000.

27. Dean, J.W.; Bowen, D.E. Management theory and total quality: Improving research and practice through theory development. Acad. Manag. Rev. 1994, 19, 392-418. [CrossRef]

28. Osterloh, M.; Frey, B.S. Motivation, knowledge, transfer and organizational forms. Organ. Sci. 2000, 11, 538-550. [CrossRef]

29. Hur, J.D.; Nordgren, L.F. Paying for performance: Performance incentives increase desire for the reward object. J. Personal. Soc. Psychol. 2016, 111, 301-316. [CrossRef] [PubMed]

30. Schein, E.H. Organizational psychology then and now: Some observations. Annu. Rev. Organ. Psychol. Organ. Behav. 2015, 2, 1-19. [CrossRef]

31. Gerhart, B.; Fang, M. Pay, intrinsic motivation, extrinsic motivation, performance, and creativity in the workplace: Revisiting long-held beliefs. Annu. Rev. Organ. Psychol. Organ. Behav. 2015, 2, 489-521. [CrossRef]

32. Tsung Jen, C. Social ties, knowledge diversity and individual creativity. J. Bus. Stud. Q. 2014, 2, 110-124.

33. Hill, S.; Wilkinson, A. In search of TQM. Empl. Relat. 1995, 17, 8-25. [CrossRef]

34. Laursen, $\mathrm{K}$. The importance of sectorial differences in the application of complementary HRM practices for innovation performance. Int. J. Econ. Bus. 2002, 9, 139-156. [CrossRef]

35. Laursen, K.; Foss, N.J. New human resource management practices, complementarities and the impact on innovation performance. Camb. J. Econ. 2003, 27, 243. [CrossRef]

36. Zhou, J.; Shalley, C.E. Research on employee creativity: A critical review and directions for future research. Res. Pers. Hum. Resour. Manag. 2003, 22, 165-217.

37. Sternberg, R.; Lubart, T. La Creatividad En La Cultura Conformista. Un Desafío a Las Masas; Paidós: Barcelona, Spain, 1997.

38. Sternberg, R. The nature of creativity. Creat. Res. J. 2006, 18, 87-98.

39. Muñoz-Doyague, M.F.; González-Álvarez, N.; Nieto, M. An examination of individual factors and employees' creativity: The case of Spain. Creat. Res. J. 2008, 20, 21-33. [CrossRef]

40. Guo, J.; Su, Q.; Zhang, Q. Individual creativity during the ideation phase of product innovation: An interactional perspective. Creat. Innov. Manag. 2017, 26, 31-48. [CrossRef]

41. Csikszentmihalyi, M. Creatividad: El Fluir Y La Psicología Del Descubrimiento Y La Invención; Paidós Transiciones: Barcelona, Spain, 1998.

42. Corazza, G.E. Potential originality and effectiveness: The dynamic definition of creativity. Creat. Res. J. 2016, 28, 258-267. [CrossRef]

43. Litchfield, R.C.; Ford, C.M.; Gentry, R.J. Linking individual creativity to organizational innovation. J. Creat. Behav. 2015, 49, 279-294. [CrossRef]

44. Cohen, M.D.; March, J.G.; Olsen, J.P. A garbage can model of organizational choice. Adm. Sci. Q. 1972, 17, 1-25. [CrossRef]

45. Jordan, J.; Jones, P. Assessing your company's knowledge management style. Long Range Plan. 1997, 30, 392-398. [CrossRef]

46. Wang, C.L.; Ahmed, P.K. The development and validation of the organisational innovativeness construct using confirmatory factor analysis. Eur. J. Innov. Manag. 2004, 7, 303-313. [CrossRef]

47. Galende, J. Analysis of technological innovation from business economics and management. Technovation 2006, $26,300-311$. [CrossRef]

48. Ait-El-Hadj, S. Gestión De La Tecnología. La Empresa Ante La Mutación De La Tecnología; Addison-Wesley Iberoamericana: Boston, MA, USA, 1990.

49. Cohen, W.M.; Levinthal, D.A. Absorptive capacity: A new perspective on learning and innovation. Adm. Sci. Q. 1990, 35, 128-152. [CrossRef]

50. Galende, J.; Suárez, I. A resource-based analysis of the factors determining a firm's R\&D activities. Res. Policy 1999, 28, 891-905.

51. Ryan, A.M.; Derous, E. The Unrealized Potential of Technology in Selection Assessment. J. Work. Organ. Psychol. 2019, 35, 85-92. [CrossRef]

52. OCDE-EUROSTAT. Oslo Manual. Guidelines for Collecting and Interpreting Technological Innovation Data, 3rd ed.; OECD Publishing: Paris, France, 2005.

53. Alegre, J.; Chiva, R. Assessing the impact of organizational learning capability on product innovation performance: An empirical test. Technovation 2008, 28, 315-326. [CrossRef]

54. Curado, C.; Muñoz-Pascual, L.; Galende, J. Antecedent to innovation performance in SMEs: A mixed methods approach. J. Bus. Res. 2018, 89, 206-215. [CrossRef]

55. Muñoz-Pascual, L.; Curado, C.; Galende, J. The triple bottom line on sustainable product innovation performance in SMEs: A mixed methods approach. Sustainability 2019, 11, 1689. [CrossRef]

56. Martínez-Lorente, A.R.; Dewhurst, F.; Dale, B.G. TQM and business innovation. Eur. J. Innov. Manag. 1999, 2, 12-19. [CrossRef]

57. Haner, U.E. Innovation quality-A conceptual framework. Int. J. Prod. Econ. 2002, 80, 31-37. [CrossRef]

58. Bodla, M.A.; Naeem, B. Creativity as mediator for intrinsic motivation and sales performance. Creat. Res. J. 2014, 26, 468-473. [CrossRef]

59. Teece, D.; Pisano, G.; Shuen, A. Dynamic capabilities and strategic management. Strateg. Manag. J. 1997, 18, 509-533. [CrossRef]

60. Zollo, M.; Winter, S.G. Deliberate learning and the evolution of dynamic capabilities. Organ. Sci. 2002, 13, 339-351. [CrossRef] 
61. Muñoz-Pascual, L.; Galende, J. The impact of knowledge and motivation management on creativity: Employees of innovative Spanish companies. Empl. Relat. 2017, 39, 732-752. [CrossRef]

62. Brix, J. Exploring Knowledge creation processes as a source of organizational learning: A longitudinal case study of a public innovation project. Scand. J. Manag. 2017, 33, 113-127. [CrossRef]

63. Pisano, G. Science Business: The Promise, the Reality, and the Future of Biotech; Harvard Business School Press: Boston, MA, USA, 2006.

64. Raman, P.; Sambasivan, M.; Kumar, N. Counterproductive work behavior among frontline government employees: Role of personality, emotional intelligence, affectivity, emotional labor, and emotional exhaustion. J. Work Organ. Psychol. 2016, 32, 25-37. [CrossRef]

65. Yoon, H.J.; Sung, S.Y.; Choi, J.N.; Lee, K.; Kim, S. Tangible and intangible rewards and employee creativity: The mediating role of situational extrinsic motivation. Creat. Res. J. 2015, 27, 383-393. [CrossRef]

66. Cohen-Meitar, R.; Carmeli, A.; Waldman, D.A. Linking meaningfulness in the workplace to employee creativity: The intervening role of organizational identification and positive psychological experiences. Creat. Res. J. 2009, 21, 361-375. [CrossRef]

67. De Buisonjé, D.R.; Ritter, S.M.; De Bruin, S.; Ter Horst, J.M.L.; Meeldijk, A. Facilitating creative idea selection: The combined effect of self-affirmation, promotion focus and positive affect. Creat. Res. J. 2017, 29, 174-181. [CrossRef]

68. Snyder, A.I.; Tormala, Z.L. Valence asymmetries in attitude ambivalence. J. Personal. Soc. Psychol. 2017, 112, 555-576. [CrossRef] [PubMed]

69. Cooper, R.B.; Jayatilaka, B. Group creativity: The effects of extrinsic, intrinsic, and obligation motivations. Creat. Res. J. 2006, 18, 153-172. [CrossRef]

70. Hannam, K.; Narayan, A. Intrinsic motivation, organizational justice, and creativity. Creat. Res. J. 2015, 27, 214-224. [CrossRef]

71. Hemlin, S. Creative knowledge environments: An interview study with group members and group leaders of university and industry R\&D groups in biotechnology. Creat. Innov. Manag. 2009, 18, 278-285.

72. Barnier, A.J.; Klein, L.; Harris, C.B. Transactive memory in small, intimate groups: More than the sum of their parts. Small Group Res. 2018, 41, 62-97. [CrossRef]

73. Hunter, S.T.; Bedell, K.E.; Mumford, M.D. Climate for creativity: A quantitative review. Creat. Res. J. 2007, 19, 69-90. [CrossRef]

74. Kwon, J.; Lee, M.; Kim, H.R. Does a creative designer necessarily translate into the creative design of a product? Exploring factors facilitating the creativity of a new product. Creat. Innov. Manag. 2015, 24, 675-692. [CrossRef]

75. Frederiksen, M.H.; Knudsen, M.P. From creative ideas to innovation performance: The role of assessment criteria. Creat. Innov. Manag. 2017, 26, 60-74. [CrossRef]

76. Hair, J.; Anderson, R.; Tatham, R.; Black, W. Multivariate Data Analysis; Prentice-Hall: Upper Saddle River, PA, USA, 2005.

77. Armstrong, J.S.; Overton, T.S. Estimating nonresponse bias in mail surveys. J. Mark. Res. 1977, 14, 396-402. [CrossRef]

78. Lepak, D.P.; Takeuchi, R.; Snell, S.A. Employment flexibility and firm performance: Examining the interaction effects of employment mode, environmental dynamism, and technological intensity. J. Manag. 2003, 29, 681-703.

79. Youndt, M.A.; Snell, S.A. Human resource configurations, intellectual capital, and organizational performance. J. Manag. Issues. 2004, 16, 337-360.

80. Hermans, R.; Kauranen, L. Value creation potencial of intelectual capital in biotechnology-empirical evidence from Finland. RD Manag. 2005, 35, 171-185.

81. Cheng, C.J.; Huang, J.W. Strategic human resource practices and innovation performance-The mediating role of knowledge management capacity. J. Bus. Res. 2009, 62, 104-114. [CrossRef]

82. De Saá-Pérez, P.; Díaz-Díaz, N.L. Human resource management and innovation in the Canary Islands: An ultra-peripheral region of the European Union. Int. J. Hum. Resour. Manag. 2010, 21, 1649-1666. [CrossRef]

83. Yli-Renko, H.; Autio, E.; Sapienza, H.J. Social capital, knowledge acquisition, and knowledge exploitation in Young technologybased firms. Strateg. Manag. J. 2001, 22, 587-613. [CrossRef]

84. Tippins, M.J.; Sohi, R.S. IT competency and firm performance: Is organizational learning a missing link? Strateg. Manag. J. 2003, 24, 745-761. [CrossRef]

85. Rodan, S.; Galunic, D.C. More than network structure: How knowledge heterogeneity influences managerial performance and innovativeness. Strateg. Manag. J. 2004, 25, 541-556. [CrossRef]

86. Subramaniam, M.; Youndt, M.A. The influence of intellectual capital on the types of innovative capabilities. Acad. Manag. J. 2005, 48, 450-463. [CrossRef]

87. Chow, W.S.; Chan, L.S. Social network, social trust and shared goals in organizational knowledge sharing. Inf. Manag. 2008, 45, 458-465. [CrossRef]

88. García-Ros, R.; Talaya, I.; Pérez-González, F. The process of identifying gifted children in elementary education: Teachers'evaluations of creativity. Sch. Psychol. Int. 2012, 33, 661-672. [CrossRef]

89. Krumm, G.; Aranguren, M.; Arán Filippetti, V.; Lemos, V. Factor structure of the Torrance tests of creative thinking verbal form $b$ in a Spanish-speaking population. J. Creat. Behav. 2016, 50, 150-164. [CrossRef]

90. Hee Kim, K. Can we trust creativity tests? A review of the Torrance Tests of Creative Thinking (TTCT). Creat. Res. J. 2006, 18, 3-14. [CrossRef]

91. Zahra, S.A.; Covin, J.G. Business strategy, technology policy and firm performance. Strateg. Manag. J. 1993, 14, 451-478. [CrossRef]

92. Hayton, J.C. Competing in the new economy: The effect of intellectual capital on corporate entreprenerurship in high-technology new ventures. RD Manag. 2005, 35, 137-155. [CrossRef] 
93. Jensen, M.B.; Johnson, B.; Lorenz, E.; Lundvall, B.A. Forms of knowledge and modes of innovation. Res. Policy 2007, 36, 680-693. [CrossRef]

94. Odoardi, C.; Battistelli, A.; Montani, F.; Peiró, J.M. Affective commitment, participative leadership, and employee innovation: A multilevel investigation. J. Work Organ. Psychol. 2019, 35, 103-113. [CrossRef]

95. Bagozzi, R.P.; Baumgartner, H. The evaluation of structural equation models and hypothesis testing. In Principles of Marketing Research; Bagozzi, R.P., Ed.; Blackwell Publishers: Cambridge, MA, USA, 1994; pp. 386-422.

96. Williams, L.J.; Gavin, M.B.; Hartman, N.S. Structural equation modeling methods in strategy research: Applications and issues. In Research Methodology in Strategy and Management; Ketchen, D.J., Jr., Bergh, D.D., Eds.; Elsevier: Oxford, UK, 2004 ; pp. 303-346.

97. Byrne, B.M. Structural Equation Modeling with AMOS: Basic Concepts, Applications and Programming; Routledge: New York, NY, USA, 2009.

98. Jöreskog, K.; Sörbom, D. LISREL 8: User's Reference Guide; Scientific Software International: Chicago, IL, USA, 1993.

99. Browne, M.W.; Cudeck, R. Alternative ways of assessing model fit. In Testing Structural Equations Models; Bollen, K.A., Long, J.S., Eds.; Sage: Newbury Park, CA, USA, 1993; pp. 136-162.

100. Ngo, L.V.; O'Cass, A. Innovation and business success: The mediating role of customer participation. J. Bus. Res. 2013, 66, 1134-1142. [CrossRef]

101. Maes, J.; Sels, L. SMEs radical product innovation: The role of internally and externally oriented knowledge capabilities. J. Small Bus. Manag. 2014, 52, 141-163. [CrossRef]

102. Groza, M.D.; Locander, D.A.; Howlett, C.H. Linking thinking styles to sales performance: The importance of creativity and subjective knowledge. J. Bus. Res. 2016, 69, 4185-4193. [CrossRef]

103. Fiss, P.C.; Sharapov, D.; Conqvist, L. Opposites attract? Opportunities and challenges for integrating large-N QCA and econometric analysis. Political Res. Q. 2013, 66, 191-235.

104. Ganter, A.; Hecker, A. Configurational paths to organizational innovation: Qualitative comparative analyses of antecedents and contingencies. J. Bus. Res. 2014, 67, 1285-1292. [CrossRef]

105. Cragun, D.; Pal, T.; Vadaparampil, S.; Baldwin, J.; Hampel, H.; DeBate, R. Qualitative comparative analysis: A hybrid method for identifying factors associated with program effectiveness. J. Mix. Methods Res. 2016, 10, 251-272. [CrossRef]

106. Johnson, R.; Onwuegbuzie, A.J. Mixed methods research: A research paradigm whose time has come. Educ. Res. 2004, 33, 14-26. [CrossRef]

107. Poorkavoos, M.; Duan, Y.; Edwards, J.S.; Ramanathan, R. Identifying the configurational paths to innovation in SMEs: A fuzzy-set qualitative comparative analysis. J. Bus. Res. 2016, 69, 5843-5854. [CrossRef]

108. Valaei, N.; Rezaei, S.; Wan-Ismail, W.K. Examining learning strategies, creativity, and innovation at SMEs using fuzzy set Qualitative Comparative Analysis and PLS path modeling. J. Bus. Res. 2017, 70, 224-233. [CrossRef]

109. Raudeliūnienè, J.; Tvaronavičienė, M.; Blažytè, M. Knowledge management practice in general education schools as a tool for sustainable development. Sustainability 2020, 12, 4034. [CrossRef]

110. Jokanović, B.; Zivlak, N.; Okanović, A.; Ćulibrk, J.; Duđak, L. The model of knowledge management based on organizational climate. Sustainability 2020, 12, 3273. [CrossRef]

111. Field, J.C.; Chan, X.W. Contemporary knowledge workers and the Boundaryless work-life interface: Implications for the human resource management of the knowledge workforce. Front. Psychol. 2018, 9, 1-10. [CrossRef]

112. Stankevičiūtè, Ž;; Savaneviciene, A. Designing sustainable HRM: The core characteristics of emerging field. Sustainability 2018, 10, 4798. [CrossRef]

113. Díaz-Carrión, R.; López-Fernández, M.; Romero-Fernández, P.M. Evidence of different models of socially responsible HRM in Europe. Bus. Ethic-A Eur. Rev. 2018, 28, 1-18. [CrossRef]

114. Abbas, J.; Sağsan, M. Impact of knowledge management practices on green innovation and corporate sustainable development: A structural analysis. J. Clean. Prod. 2019, 229, 611-620. [CrossRef]

115. Abdi, K.; Mardani, A.; Senin, A.A.; Tupenaite, L.; Naimaviciene, J.; Kanapeckiene, L.; Kutut, V. The effect of knowledge management, organizational culture and organizational learning on innovation in automotive industry. J. Bus. Econ. Manag. 2018, 19, 1-19. [CrossRef]

116. Palm, K.; Bergman, A.; Rosengren, C. Towards more proactive sustainable human resource management practices? A study on stress due to the ICT-mediated integration of work and private life. Sustainability 2020, 12, 8303. [CrossRef]

117. Kalliath, T.; Kalliath, P.; Chan, C. Work-family conflict, family satisfaction and employee well-being: A comparative study of Australian and Indian social workers. Hum. Resour. Manag. J. 2017, 27, 366-381. [CrossRef]

118. Kianto, A.; Vanhala, M.; Heilmann, P. The impact of knowledge management on job satisfaction. J. Knowl. Manag. 2016, 20, 621-636. [CrossRef]

119. Zheng, J.; Wu, G.; Xie, H. Impacts of leadership on project-based organizational innovation performance: The mediator of knowledge sharing and moderator of social capital. Sustainability 2017, 9, 1893. [CrossRef]

120. Muñoz-Pascual, L.; Galende, J.; Curado, C. Human resource management contributions to knowledge sharing for a sustainabilityoriented performance: A mixed methods approach. Sustainability 2020, 12, 161. [CrossRef]

121. Muñoz-Pascual, L.; Galende, J. Sustainable human resource management and organisational performance: An integrating theoretical framework for future research. Small Bus. Int. Rev. 2020, 4, 281. [CrossRef] 
122. Muñoz-Pascual, L.; Galende, J. Ambidextrous relationships and social capability as employee well-being: The secret sauce for research and development and sustainable innovation performance. Int. J. Environ. Res. Public Health 2020, 17, 3072. [CrossRef] [PubMed]

123. Muñoz-Pascual, L.; Galende, J. Ambidextrous knowledge and learning capability: The magic potion for employee creativity and sustainable innovation performance. Sustainability 2020, 12, 3966. [CrossRef]

124. Yang, P.; Wang, X. COVID-19: A new challenge for human beings. Cell. Mol. Immunol. 2020, 17, 555-557. [CrossRef]

125. Le, T.T.; Andreadakis, Z.; Kumar, A.; Román, R.G.; Tollefsen, S.; Saville, M.; Mayhew, S. The COVID-19 vaccine development landscape. Nat. Rev. Drug Discov. 2020, 19, 305-306. [CrossRef]

126. Muñoz-Pascual, L.; Curado, C.; Galende, J. How does the use of information technologies affect the adoption of environmental practices in SMEs? A mixed methods approach. Rev. Manag. Sci. 2021, 15, 75-102. [CrossRef]

127. Crespo, N.F.; Curado, C.; Oliveira, M.; Muñoz-Pascual, L. Entrepreneurial capital leveraging innovation in micro firms: A mixed-methods perspective. J. Bus. Res. 2021, 123, 333-342. [CrossRef] 